
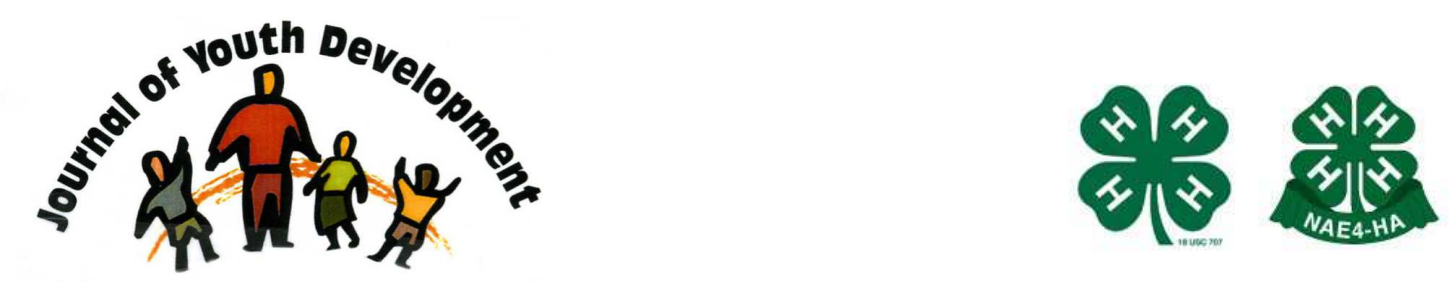

Bridging Research \& Practice

\title{
Effective, Efficient Online Training in Cooperative Extension
}

\author{
Jane Chin Young \\ Agriculture and Natural Resources \\ University of California \\ Novato, CA \\ jchin@ucanr.edu \\ Linda Marie Manton \\ Agriculture and Natural Resources \\ University of California \\ Davis, CA \\ Immanton@ucanr.edu
}

Steven M. Worker

Agriculture and Natural Resources

University of California

Davis, CA

smworker@ucanr.edu

Anna C. Martin

Agriculture and Natural Resources

University of California

Stockton, CA

acmartin@ucanr.edu 


\title{
JOURNAL OF YOUTH DEVELOPMENT \\ bridging research and practice

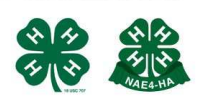

Volume 9, Number 3, Fall 2014

Article 140903PA002

\section{Effective, Efficient Online Training in Cooperative Extension}

\author{
Jane Chin Young, Linda Marie Manton, Steven M. Worker and Anna C. Martin \\ University of California
}

\begin{abstract}
In order to keep pace with media and communications trends in education, Cooperative Extension (CE) faces the need to shift from traditional face-to-face delivery to online alternatives. This exploratory study focused on evaluating the effectiveness of ondemand, interactive online training compared to its face-to-face counterpart. Targeted for CE staff and volunteers whose work impacts youth, families and communities, the design centered on the university's cost-effective in-house technology tools. The study results make the case for online delivery as effective and efficient. Strategies for developing a process for online delivery in CE are also offered.
\end{abstract}

\section{Introduction}

Technology is quickly changing the way the world communicates and accesses information. At the same time, the economy has shifted to one of significantly reduced resources for informal as well as formal education and outreach. As a result, organizations are tasked to become more efficient and effective as a standard rather than as an option. In response to the challenge for Cooperative Extension to keep pace with trends, work with less, reach new audiences, and remain relevant, this study integrated research, extension, and technology to explore online communications as an alternative for in-person programming. The study centered on the development of a web-based format using cost-effective internal resources, and comparing the effectiveness of the delivery to its traditional face-to-face, onsite counterpart. Outcomes support the online delivery as effective and efficient. The study resulted in a prototype for web-based delivery, with strategies that may enhance any type of online programming.

\section{Background}

The increased accessibility of information has caused a rapid change from experts providing information to people finding it for themselves. In addition, momentum for online education 
alternatives to classroom-based instruction has been building for the past few decades. Research on online learning represents broad findings, the empirical literature is mixed, and at least two meta-analyses have concluded that there are few significant differences in academic outcomes between online and classroom education (e.g., Bernard, et al., 2004; U.S. Department of Education, 2010). This research has helped dispel the myth that online education is inferior to in-person education. Some studies of college courses support instructional structure as more significant than the delivery, and that similar controls with content, assessments, and demographics support reduces the variation between deliveries (Driscoll, 2012).

As a result of social, technological, and economic trends, Cooperative Extension has been confronted with re-identifying its role in this new distribution of knowledge (Seger, 2011). A major challenge for Cooperative Extension is advancing programming beyond its tradition of face-to-face interactions with clientele (Diem, Hino, Martin, \& Meisenbach, 2011). Though Extension studies on online program delivery have been limited in size and scope, information has been collected that supports the common conception that younger people use technology more (Guenthner, \& Swan, 2011). There have been studies with selective factors, such as recruitment targeted for clientele who sought online learning (Kaslon, Lodl, \& Greve, 2005), and surveying clientele on their use of online resources for information (Stevenson, et al., 2011). In some cases, substantial funding to employ the services of experts was used to develop and test online sites (Zamora, et al., 2012). To expect Extension to stay ahead may be unrealistic, but an inevitable balance is needed between satisfying traditional clientele who prefer face-to-face interaction, with reaching out to new and future clientele online (Seger, 2011). What sets this study apart from others is its application of internal Cooperative Extension staff resources to pilot online delivery of a traditional face-to-face training. The result is a cost-effective and efficient alternative for staff and volunteer programming.

\section{Method}

The study centered on the development of a web-based, on-demand training program using internal management technology tools in combination with those publicly available. Tools developed by the university include a content management system for website design, and a survey tool for pre- and post-quizzes and evaluation. University contracted software included: Camtasia Relay and Adobe Presenter for recording narrated visuals. Common software included: PowerPoint for presentations, MP4 for video, and Word and PDF for downloadable worksheets and handouts.

Developed by nutrition education academics, the food safety education curriculum known as Make It Safe, Keep It Safe was identified as the subject topic. This selection was based on the curriculum's history of consistent content and onsite delivery for internal staff and volunteer training. In addition, food safety education is a common healthy living theme for youth, families and communities.

There were three phases to the study. Phase one was comprised of a series of onsite trainings with an updated version of the curriculum. Evaluation tools were developed for knowledge and delivery. In phase two, a parallel online version of the onsite training was developed, integrating a variety of technology tools. The approach applied considered site design, key concepts reflected in the quizzes, interactive components, diversity in visual images, and offline capabilities. In phase three, the site was field-tested with a sample of staff and volunteers, 
followed by piloting of an improved version with a cross-section of statewide participants. The result was a prototype site, with strategies for site development.

Both onsite and online trainings were open to all counties, with recruitment for a crossrepresentation that included the different regions of the state, and both rural and urban counties. Participants were staff, 4- $\mathrm{H}$ adult and teen volunteers, and master gardener volunteers that were required to meet an internal training requirement during the pilot period. Participants for both deliveries were primarily White female. Half of the adult participants had less than four years of volunteer service.

The training site layout was designed with units structured as sequential lesson modules that can function as stand-alone as well as complementary components. For the core concepts, PowerPoint was selected for its familiar and prominent use in Extension (Johnson, 2011). The concepts were supported by interactive components including videos, online recordings, web links, and surveys.

\section{Evaluation}

For both onsite and online trainings, identical tools were used to gather participant knowledge and process opinions. Only data from adult participants were reported.

To assess knowledge gain, pre- and post-quizzes containing 11 multiple choice questions were administered. The instrument, "Food Safety Knowledge Quiz," was developed by Cooperative Extension food safety experts. Questions were scored dichotomously as either "correct" (1 point) or "incorrect" (0 points), and then summed for a final participant score. To collect process-related opinions, participants rated ten items on a five-point Likert scale ("Process"), plus responded to three open-ended questions on how the information acquired would be used. Due to the limitations of the technology, online participants could not be required to take the pre-test or evaluation in order to complete the training, resulting in lower response rates.

\section{Results}

\section{Knowledge Outcomes}

Participants improved their knowledge in both conditions calculated using a paired t-test of the means between pre and post-tests. The onsite pre-test mean was 9.0 (1.17 SD) and post-test mean was $10.4(0.79$ SD), demonstrating a statistically significant increase $(n=39, p<.001)$ in knowledge gained from pre to post on the Food Safety Knowledge Quiz. The online pre-test mean was 9.3 (1.20 SD) and post-test mean was 10.9 (0.34 SD) which was also a statistically significant improvement $(n=32, p<.001)$. An independent t-test of the post-test means between onsite and online revealed a significant difference $(p<.002)$. This indicates that the online participants, on average, performed better on the post-test quiz than those in the face-to-face condition. (See Table 1) 
Table 1

Pre/post Food Safety Knowledge Quiz results of percentage of questions answered correctly

\begin{tabular}{|c|c|c|c|c|}
\hline \multirow[b]{2}{*}{$\begin{array}{l}\text { Questions } 1-2 \text { and } 5-11 \\
\text { Multiple choice with four answer choices }\end{array}$} & \multicolumn{2}{|c|}{ Face-to-Face $(n=39)$} & \multicolumn{2}{|c|}{ Online $(n=32)$} \\
\hline & Pre-Test & Post-Test & Pre-Test & $\begin{array}{l}\text { Post- } \\
\text { Test }\end{array}$ \\
\hline $\begin{array}{l}\text { 1. What is the most common cause of } \\
\text { foodborne illness? }\end{array}$ & $100 \%$ & $100 \%$ & $96.8 \%$ & $93.6 \%$ \\
\hline $\begin{array}{l}\text { 2. Which group is the highest risk for foodborne } \\
\text { illness? }\end{array}$ & $100 \%$ & $97.4 \%$ & $93.6 \%$ & $100 \%$ \\
\hline $\begin{array}{l}\text { 3. True or False: Hand washing is the most } \\
\text { effective way to stop the spread of illness. }\end{array}$ & $89.7 \%$ & $100 \%$ & $100 \%$ & $100 \%$ \\
\hline $\begin{array}{l}\text { 4. Are chemical sanitizers an acceptable } \\
\text { replacement for hand washing? }\end{array}$ & $71.8 \%$ & $94.9 \%$ & $76.9 \%$ & $100 \%$ \\
\hline $\begin{array}{l}\text { 5. What is an example of cross-contamination } \\
\text { that is high-risk for leading to foodborne } \\
\text { illness? }\end{array}$ & $97.4 \%$ & $94.9 \%$ & $93.6 \%$ & $100 \%$ \\
\hline $\begin{array}{l}\text { 6. What is the most accurate way to determine } \\
\text { if food is adequately cooked? }\end{array}$ & $97.4 \%$ & $100 \%$ & $93.6 \%$ & $100 \%$ \\
\hline $\begin{array}{l}\text { 7. Food should be chilled to reduce the speed of } \\
\text { bacteria growth. What is the recommendation } \\
\text { for the maximum time perishable food should } \\
\text { be at room temperature (under } 90 \mathrm{~F} \text { ) before } \\
\text { refrigeration? }\end{array}$ & $53.9 \%$ & $89.7 \%$ & $51.6 \%$ & $93.6 \%$ \\
\hline $\begin{array}{l}\text { 8. What is the recommended safest and fastest } \\
\text { way to chill large containers of food? }\end{array}$ & $33.3 \%$ & $69.2 \%$ & $51.6 \%$ & $100 \%$ \\
\hline 9. What is the safest way to thaw food? & $92.3 \%$ & $92.3 \%$ & $90.3 \%$ & $100 \%$ \\
\hline $\begin{array}{l}\text { 10. What is the recommended temperature for } \\
\text { the refrigerator? }\end{array}$ & $84.6 \%$ & $100 \%$ & $96.8 \%$ & $100 \%$ \\
\hline $\begin{array}{l}\text { 11. To what temperature should leftovers be } \\
\text { reheated? }\end{array}$ & $74.4 \%$ & $100 \%$ & $80.7 \%$ & $100 \%$ \\
\hline Mean Correct Answers & $81.4 \%$ & $94.4 \%$ & $84.1 \%$ & $98.8 \%$ \\
\hline
\end{tabular}

\section{Process Outcomes}

Participant responses to the online format were very positive. Though the scores for the faceto-face delivery were higher, the scores for the online format were still very good. (See Charts 1 and 2) When considering issues of training-related expenses, in contrast to onsite delivery, the online format afforded significant savings in expenses to administer. 


\section{Chart 1}

Adult participant opinions on information and delivery based on Likert rating scale.

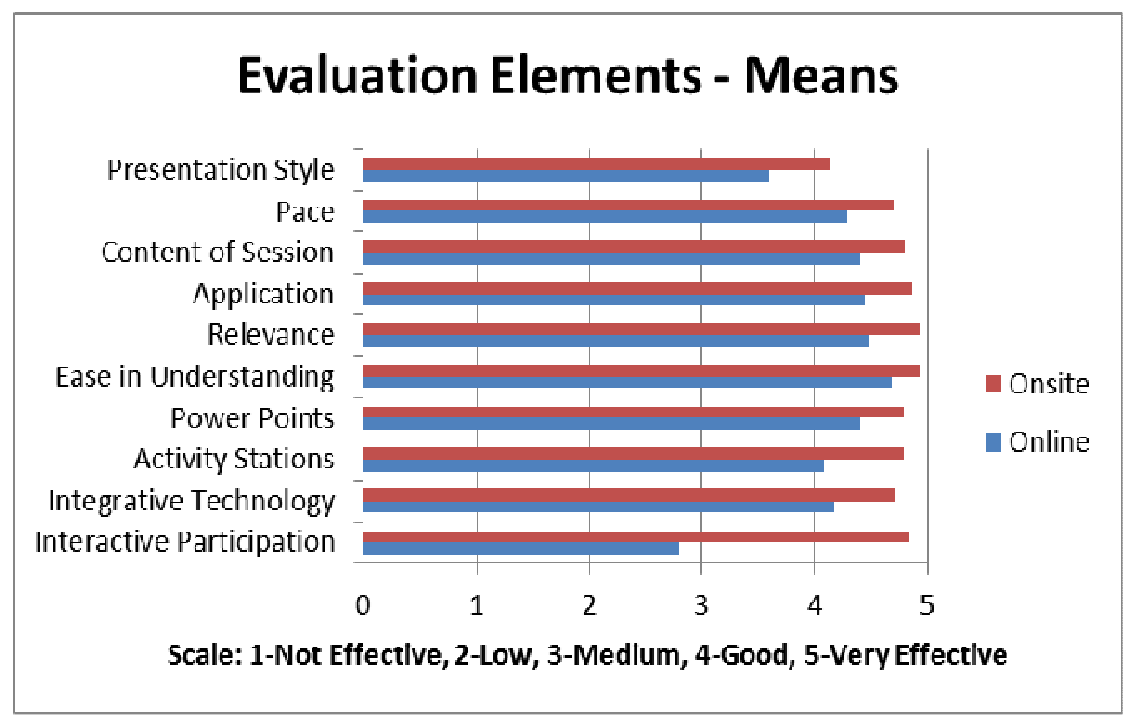

Chart 2

Training expectations for online and onsite participants

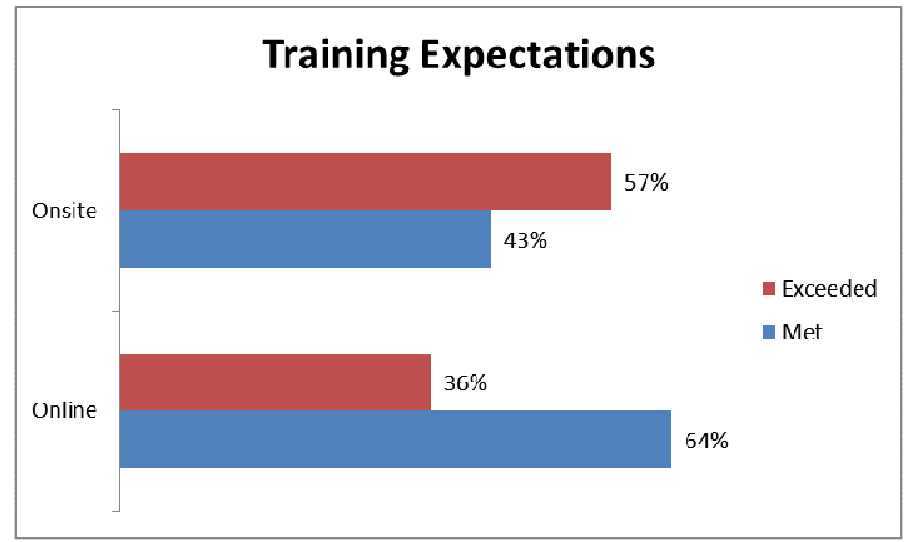

\section{Discussion}

Overall, data from the online training indicated that the delivery was effective and efficient. Participant feedback indicated that the information gained along with the option of an online format would be very beneficial for volunteers' program work.

In the twelve-month period following the conclusion of the pilot, three actions demonstrate the success of the project:

1. The pilot was represented by eleven counties. Since the completion of that study, 210 additional participants representing seven additional counties have taken the online training. These participants were comprised of $14 \%$ staff, $79 \%$ volunteers, and $7 \%$ others. 
2. Cooperative Extension's Nutrition, Family \& Consumer Science (NFCS) program is currently conducting a research project that builds upon and expands the pilot prototype. The new project is bilingual English/Spanish, and extends its reach to a broader audience that includes NFCS program clientele and the public.

3. Staff and volunteers continue to build their own tech capacity both as site developers and as training participants. The knowledge and skills acquired are transferrable to other training sites.

\section{Conclusion}

The key conclusion of the study is that online delivery is an effective and efficient delivery for staff and volunteer development. The study identified a process resulting in a prototype, one that combined the joint efforts of staff in subject content, policy, training and certification, and technology.

Though more research needs to be conducted on the topic of online delivery as an alternative for in-person programming, there are some strategies that can be taken from this pilot study for future consideration:

1. A framework that includes the following elements: target audience, tech requirements, data collection, desired outcomes, scoring, evaluation, and roles.

2. Site design that is easy to navigate and allows re-entry, and includes an introductory section with visual illustrations on how to use the site.

3. Pre- and post-knowledge quizzes to help participants to focus on key concepts during the training.

4. Interactive as well as view-only components, integrating observation, interpretation, prediction, problem-solving, and comparing.

5. Images and voices of staff, volunteers and teens that mirror face-to-face sessions, to lend authenticity as well as diversity.

6. Additional resources, such as web links, for supplemental and expanded learning.

7. Offline versions of all training components for use by trainers and/or participants in nonconnected settings.

Participant feedback indicates clientele are positioned to receiving increased training through online formats, and can be active participants in the learning process. This study supports the case for staff adaptation and adoption for online training as one of an investment for the future.

\section{References}

Bernard, R.M., Abrami, P.C., Lou, Y., Borokhovski, E., Wade, A., Wozney, L., Wallet, P.A., Fiset, M., Huang, B. (2004). How does distance education compare with classroom instruction? $A$ meta-analysis of the empirical literature. Review of Educational Research, 74(3), 379-439.

Diem, K.G., Hino, J., Martin, D., \& Meisenbach, T. (2011). Is Extension ready to adopt technology for delivering programs and reaching new audiences? Journal of Extension [On-line], 49(6) Article 6FEA1. Available at: http://www.joe.org/joe/2011december/a1.php 
Driscoll A., Jicha, K., Hunt, A., Tichavsky, L., \& Thompson, G. (2012, May 16). Can online courses deliver in-class results? SAGE Journals [On-line] 40(4) 312-331. Retrieved from: http://tso.sagepub.com/content/40/4/312.full

Guenthner, J.F., \& Swan, B.G. (2011). Extension learners' use of electronic technology. Journal of Extension [On-line], 49(1) Article 1FEA2. Available at:

http://www.joe.org/joe/2011february/a2.php

Johnson, S.B. (2011). Delivery of PowerPoint videos on the world wide web. Journal of Extension [On-line], 49(2) Article 2TOT9. Available at: http://www.joe.org/joe/2011april/tt9.php

Kaslon, L., Lodl, K., \& Greve, V. (2005). Online leader training for 4-H volunteers: A case study of action research. Journal of Extension [On-line], 43(2) Article 2FEA4. Available at: http://www.joe.org/joe/2005april/a4.php

Seger, J. (2011). The new digital [st]age: Barriers to the adoption and adaptation of new technologies to deliver extension programming and how to address them. Journal of Extension [On-line], 49(1) Article 1FEA1. Available at: http://www.joe.org/joe/2011february/a1.php

Stevenson, J.L, Moore, D.A, Newman, J., Schmidt, J.L., Smith, S.M., Smith, J., \& Kerr, S. (2011). Assessing the Need for an On-Line Educational Module for Volunteer Leaders on BioSecurity in Washington State 4-H Livestock Projects. Journal of Extension [On-line] 49(3) Article 3FEA9. Available at: http://www.joe.org/joe/2011june/a9.php

U.S. Department of Education. (2010). Evaluation of evidence-based practices in online learning: A meta-analysis and review of online learning studies. Washington, D.C. Retrieved from: http://www2.ed.gov/rschstat/eval/tech/evidence-based-practices/finalreport.pdf

Zamora, D.S., Blinn, C.R., Chura, D.T., Sagor, E.S., Coyle, L.D., \& Domke, G.M.(2012). Converting face-to-face curricula for online delivery: Lessons learned from a biomass harvesting guidelines curriculum. Journal of Extension [On-line], 50(5) Article 5FEA5. Available at: http://www.joe.org/joe/2012october/a5.php

(C) Copyright of Journal of Youth Development Bridging Research and Practice. Content may not be copied or emailed to multiple sites or posted to a listserv without copyright holder's express written permission. Contact Editor at: patricia.dawson@oregonstate.edu for details. However, users may print, download or email articles for individual use. 